ILDIKÓ ASZTALOS MORELL ${ }^{1}$

SOCIAL FARMING AS A MEANS OF POVERTY REDUCTION IN RURAL HUNGARY

Dol: 10.18030/sOCIO.HU.2015EN.83

\title{
ABSTRACT
}

This paper is to set focus on innovative ways to combat food poverty in rural Hungary. Food poverty is associated with malnutrition which can refer both to the lack of food and its dissatisfying quality. Food poverty in the post-socialist rural context does not emerge as a consequence of natural catastrophes or lacking accessibility to food. Rather, it is the outcome of the unequal distribution of incomes and resources. Methods of overcoming food-poverty emerge primarily in the interplay between post-socialist welfare institutions and civil society initiatives, even if market agents occupy an increasing role in neo-neoliberal regimes as donators of charity and resources or as collaborators in poverty alleviation projects. Municipalities work within the paradigms of the welfare state and its social benefit system as redistributors of state resources, in contrast civil society agents represent partial interests and work from principles independent of the state redistributive logic.

Therefore, it is of interest to explore in which way poverty relief programmes put emphasis on the importance of community development and participation of marginalized groups in the development of individual and group resources necessary for overcoming their exclusion. The paper explores municipality versus civil organization approaches along the dimensions of agency; whether and if so in which way these social food projects worked for the empowerment of marginalized groups. In this pursuit I focus on immaterial aspects of empowerment, where, as argued above, the development of social resources constitutes a central role.

Furthermore, the paper explores the differences and potential synergies between municipality and civil organization based social agriculture projects aiming to combat marginalization welfare dependency.

Keywords: food poverty, community development, workfare, social farming

1 PhD, Senior Research Fellow at Uppsala Centre for Russian and Eurasian Studies, Uppsala University; and Associate Professor at Mälardalen University. 
ILDIKÓ ASZTALOS MORELL

\section{SOCIAL FARMING AS A MEANS OF POVERTY REDUCTION IN RURAL HUNGARY}

\section{INTRODUCTION}

This paper is to set focus on innovative ways to combat food poverty in rural Hungary. Food poverty is associated with malnutrition which can refer both to the lack of food and its dissatisfying quality. Food poverty in the post-socialist rural context does not emerge as a consequence of natural catastrophes or lacking accessibility to food. Rather, it is the outcome of the unequal distribution of incomes and resources. Methods of overcoming food-poverty emerge primarily in the interplay between post-socialist welfare institutions and civil society initiatives, even if market agents occupy an increasing role in neoliberal regimes as donators of charity and resources or as collaborators in poverty alleviation projects. Municipalities work within the paradigms of the welfare state and its social benefit system as redistributors of state resources, in contrast civil society agents represent partial interests and work from principles independent of the state redistributive logic.

While promoters of a basic income system argue for the advantages of a system where welfare recipients maintain their autonomy in deciding which way they secure their subsistence from cash welfare transfers, conservative welfare regimes promote models which prioritize in nature benefits. However, neither basic income or in nature benefits are approaches free from passive transfer of benefits. The dilemma between giving a fish or the net prevails, and innovative municipalities as well as civil organizations introduce methods that emphasize the importance of know-how transfer. Another important concern is how efforts can contribute to improvement sustainable in the long-term. Most benefit and relief programmes focus on an individual perspective, despite of research indicating the collective forces contributing to the creation and reproduction of marginalities. Approaches differ depending on their perception of need as caused by individual weaknesses or by structural marginalization. They differ also regarding the degree they emphasize individual and/or groupbased empowerment as means of poverty relief.

According to Giddens (1984): "The ultimate goal of development should be human autonomy or agency - the capacity of people to order their world, the capacity to create, reproduce, change, and live according to their own meaning systems, to have the powers to define themselves as opposed to being defined by others". Bhattacharyya (2004) argues further along the lines of Giddens that empowerment and capacity building are not ends in themselves but "means for the higher end of agency" (13). A development agenda without agency treats the poor as "clients" rather than acting with them. "Community development in order to promote agency aims at generating critical consciousness, addressing problems that the affected people "own" and define, and take active measures to solve." (Bhattacharyya, 2004: 13) Agency assumes cognitive participation in "defining the problems, explaining their causes and proposing remedies" (ibid.: 20) which is to be reinvested into the subjects of development. 
Therefore, it is of interest to explore in which way poverty relief programmes put emphasis on the importance of community development and participation of marginalized groups in the development of individual and group resources necessary for overcoming their exclusion. The paper explores municipality versus civil organization approaches along the dimensions of agency; whether and if so in which way these social food projects worked for the empowerment of marginalized groups. In this pursuit I focus on immaterial aspects of empowerment, where, as argued above, the development of social resources constitutes a central role. Furthermore, the paper explores the differences and potential synergies between municipality and civil organization based social agriculture projects aiming to combat marginalization welfare dependency.

FOOD POVERTY, MARGINALITIES AND DISEMBEDMENT OF RURAL COMMUNITIES FOLLOWING THE POSTSOCIALIST TRANSITION TO CAPITALISM?

A key indicator of poor living conditions is the presence of food poverty. Although food poverty can be observed in the whole of the EU, its level differs. The proportion of those who were malnourished ${ }^{2}$ due to material need in 2011 showed a gap between EU 15 and EU 10 countries. The proportion of the malnourished was measured to be $6.9 \%$ in EU 15 and 20.5\% in EU 12. Its level was 29\% in Hungary, 21.2\% in Romania and 50.8\% in Bulgaria (Somai 2013: 187).

Generally, the proportion of household budgets spent on food is a good indicator of social inequalities. In CEE countries the proportion of the household budget spent on food is higher (30\%) compared to EU 15 countries (10-15\%) (EEA 2005: 17-18). This is not counting that the absolute level of expenditures on food per capita are more than 2.5 times as high in EU 15 countries compared to new member states. Furthermore, there is even a difference in the composition of the "food basket". People in CEE countries eat half the amount of fruit, fish, seafood, cheese and red meat compared to EU 15 citizens (EEA 2005). Declining household expenditure on food has been related to the transition to capitalism (SEI-T 2004).

In the case of Hungary, kg per capita food-consumption declined during the transition. In 2013 the total weight of per capita food consumption was $87.6 \%$ of the level in 1989 . The decline during the post-socialist period was most sizeable in the cases of meat (to 71\%), milk (78\%) and egg (61\%) consumption, while it increased mildly for potatoes and vegetables (KSH 2014). Food consumption is a measure of social inequalities. The proportion of food expenditure in Hungary was highest among the least educated households (36.7\%) with physical worker household-heads (34.2\%) and those in the first income quintiles (38.2\%) (Simonovits et al. 2012: 72). Food poverty hits families with children harder. The per capita food consumption is negatively related to the number of children in a family, the higher the number of children in a family the lower the level of per capita consumption of eggs, meat, vegetables and milk products. Food poverty is a growing problem for families living below the minimum standard of living.

Poverty also has an ethnic dimension. In Hungary, according to TÁRKI's longitudinal survey studies the proportion of measured poverty rate ${ }^{3}$ was $10 \%$ among non-Roma heads of households while it was $68 \%$ among

2 Along with Somai (2013: 187) I use the definition of malnourishment as affecting those who could not afford a meal with meat, chicken, fish or its vegetarian equivalent every second day.

3 The TÁRKI measure of poverty rate was those falling below the poverty line of 202 thousand HUF in 2000 and 540 thousand HUF in 
Roma in 2000 . This figure increased to $12 \%$ among non-Roma heads of households while it increased to $76 \%$ of Roma heads of households by 2012 (Gábos et al. 2012: 53). The proportion of households falling under the poverty rate were substantially higher in rural villages (23\%) than both in the capital (6\%) and cities (17\%) (Gábos et al. 2012: 53).

According to a comparative UNDP survey from 2002 food poverty among Roma is conspicuously higher in rural settlements. On the question "Were there period during the last year when your family did not have enough to eat?" $51 \%$ of urban and $43 \%$ of rural households answered no in five CEE countries (Bulgaria, Romania, Hungary, Slovakia and Check Republic). Meanwhile, 12\% of urban and 19\% of rural respondents answered yes on the statement "We are constantly starving". Highest was the proportion of those answering so in Bulgaria (close to 40\%) and Romania (over 30\%), while in Hungary around 3\% answered yes on this question (42). Most alarming is that the degree of deprivation increases with the number of children in the households, which indicates the alarming presence of child malnutrition. In 2002, 50 \% of Bulgarian, 40\% of Romanian and $10 \%$ of Hungarian children in Roma families indicated in the sample that they are constantly starving (48).

Starvation is the second most common strategy after informal money borrowing in most countries for coping with poverty (close to $60 \%$ of households in Bulgaria and 50\% in Romania) resort to this. Meanwhile, the UNDP report concludes that: "Moneylenders at times act as criminal organization and are a major factor encouraging criminality in Roma communities" (50). Thus, starvation seems the last resort before turning to moneylenders. ${ }^{4}$

Food poverty is closely related to poverty at large. The UNs Millennium Development Goals (MDGs) aimed to engage governments to work for the diminishing of poverty for marginalized groups. This contained the goal to bring to half the proportion of those living below the standard of PPP\$1 (\$1 per person per day) for developing and PPP\$4 (\$4 per person per day) for developed countries. In new EU member countries impoverishment hits especially Roma minorities. A UNDP report from 2002 provides an alarming picture of the living conditions of Roma households residing in areas with larger concentration of Roma. The surveyed Roma populations fall below these MDGs in all CEE countries. Bulgaria and Romania are worse on poverty indicators, $29 \%$ in the Bulgarian and $41 \%$ in the Romanian sample lived below PPP\$1. ${ }^{5}$ In Hungary, $1 \%$ of the surveyed households fell under this category. The proportion of those living below PPP\$ 4 was $82 \%, 85 \%$ and $88 \%$ respectively. In the Czech Republic the situation of Roma is the least impoverished from the 5 CEE countries. Roma populations in the survey indicate high levels of subjective poverty: $32 \%$ of the participants in the survey in Bulgaria, the Czech Republic, Hungary, Slovakia and Romania declared that "they live in misery", the highest proportion estimating their livelihood in this way was in Bulgaria and Romania.

2012 per capita household incomes. This figure is calculated as $60 \%$ of the median value of the yearly household income (nett 792 thousand HUF in 2012 calculated according to the equivalent of the OECD2 scale (Gábos et al. 2012: 38).

4 For the Hungarian conditions see even Béres and Lukács (2008).

5 Based on responses to the questions. "How much money did your household spend last month?" and "How many people live in your household?" Data in local currencies were converted into \$ using average annual exchange rate for 2001. UNDP 2002: 47. 


\section{CAUSES OF MARGINALIZATION: DE-INDUSTRIALIZATION, NEOLIBERAL WELFARE STATE AND ENHANCED ETHNIC/SOCIAL MARGINALIZATION}

Ethnified processes of rural marginalization followed the transition to capitalism in the CEEs (Szalai 2007). Emerging neoliberal welfare states in the context of EU integration and restrictive welfare policies enforced by global financial institutions created austerity measures unfavourable for the emergence of sustainable models of rural development in resource poor regions. Processes of post-socialist integration into a global capitalist market unembedded previous ongoing ethnic integration into a planned economic system (Ladányi-Szelényi 2004). State socialist work societies incorporated even low-skilled segments of the labour reserve, since work was not only a right but also a duty, and the demand for work was exacerbated by the resource driven development of soft budgets (Kornai 1980).Towards the end of the eighties this state socialism increasingly tolerated mixed social and economic targets for operation (Szelényi et al. 1988).

In the rural context synergistic relations developed between households, local agricultural production co-operatives and a national/international market channelling products from low resource based integrated producers, maintaining marketing integration and transfer of high-technological know-how (Swain 1985, Kovách 1988). Agricultural co-operatives worked in synergy with local municipal authorities for the social cohesion of communities. Depending on regional preconditions, rural residents served also the reserve army of surrounding industries as commuters, maintaining a strong secondary household based production in their rural residences, rather than moving into urban centres (Szelényi et al. 1988). During state socialism wide-spread household based production became integrated into state socialist marketing institutions. Informal and second economies integrated further marginal labour reserves, including marginalized Roma rural residents (Szuhay 2005).

In the transition process de-industrialization as well as de-collectivization cut off rural settlements from their key channels of integration into the dominant economic system (mode of production) (Asztalos Morell 1999), and integration that also promoted a household based production (form of production). Rather, the un-embedding was followed by the mass decline in household based production practices ${ }^{6}$ also exacerbating processes of rural impoverishment. With this decline even the subsistence opportunities for marginalized groups often utilizing share-cropping systems disappeared. With the decline of household based production the commodification of food expanded even in rural communities that hit marginalized groups without their own production resources especially hard. Commodification of food coincided with the loss of work and as a consequence employment based incomes. This led, with the exception of well-integrated regions, to welfare dependent rural idleness.

EU accession was a major facilitator of the transition to capitalism as well as to a neoliberal welfare model. To start with the perception was that mass-unemployment the displacement of labour from the closed down former state socialist primary and secondary sectors and the concomitant increase in unemployment would be temporary. Market mechanisms were expected to inject new impulses and create new working op-

6 There were 1,4 million households engaged with agricultural production in 1991. The number of these declined to 618 thousand by 2007 (Kovách 2010: 104) and to 482 thousand by 2013 (KSH 2013: 2). Half of the farms (egyéni gazdaság) produced only for self-consumption, and an additional 32\% sold produce beyond own consumption (Kovách 2010: 105). 
portunities. However, the emergent recovery has not been capable of reintegrating the previously displaced low-skilled workforce, creating a permanent underclass of a marginalized population dependent on welfare subsidies. A low economic activity rate and a high proportion of those dependent on welfare subsidies prevailed. In 2011 Hungary's economic activity rate was the second lowest after Greece within the EU: 56.2\% compared to the EU average of 64.1\% (OECD 2014).

Emergent neoliberal critique of welfare dependency led to the establishment of the public work institution in 1996. Municipalities became obliged to organize public work from 2000 onward. Meanwhile, it became a central tool for counteracting unemployment from 2009 as part of the "Way to work" [Út a munkához] strategy of the Socialist-Liberal coalition. The conservative government renamed this strategy as START, reducing eligibilities attached to it several times between 2011 and 2015. Public work as a strategy to overcome long-term unemployment was subjected to extensive and varied criticism describing public work as a "cul de sac", rather than leading out of exclusion from the labour market, and was accused of being non-voluntary and having punitive features. Studies indicate that the rate of return to the labour market even decreased in villages using extensive public work programmes (Csoba 2010, MSH 2014, Fazekas-Scharle 2012, Köllö-Scharle 2011).

Municipality strategies in small-size settlements adopting "Way to work" programmes showed great variation. Paradoxically, disciplinary potentials in the construction of public work were more likely to be used by prosperous municipalities, which on the other hand had more access to experts allowing more resourceful adaptations of public work compared to the more disadvantaged settlements.

Public work, sharing some features with other EU workfare strategies (Junestav 2004, Clasen-Clegg 2011), was stream-lined after 2010 by the national conservative [Fidesz] government. The Fidesz government has further accentuated the "work based society" incorporating the duty to work in the Constitution: "every person shall be obliged to contribute to the enrichment of the community to their best ability and potential", and turn to social benefits to be determined according to "the usefulness of the beneficiaries' activities for the community". Thus, article 19 excludes "idle beneficiaries" from rights (Szikra 2014). A new Labour Code was accepted: unemployment insurance was cut to 3 months (modification of Act IV/1991); social assistance was lowered to $15 \%$ of the average wage (modification of Act III/1993); social subsidies were made dependent on at least 30 days work participation; the welfare client claimants had to accept employment opportunities regardless of educational level; in absence of such they had to participate in public work programmes (Act $\mathrm{CVI} / 2011$ ). Claimants became exposed to behavioural codes, necessitating the requirement to keep gardens tidy (Act III/1993), and since 2013, to ensure that their children are not truant from school, otherwise claimants can be excluded. Meanwhile, the amount of labour hours for public work increased to 8 hours per day, while public work is not incorporated under the protection of the Labour Code. Payments are weekly and lowered to $70 \%$ of the minimum wage. Thus, the punitive elements of workfare increased. Meanwhile, municipalities are not obliged to provide public work for all unemployed. Exclusionary stipulations open for misuse by local municipalities and examples of misuse have been addressed by civil rights associations, as well as by the Ombudsman of Fundamental Rights (2012: 2). (TASZ 2013, Szikra 2014) 
In Hungary, welfare provision is a municipal responsibility, while resource-weak municipalities lack longterm, viable instruments for fighting exclusion in the context of the economic recession (Szalai 2007). The basic form of public work [közfoglalkoztatás] is financed to different degrees (between 70-90\%) from the state budget to partially compensate municipalities. Nonetheless, resource poor municipalities might not have the resources to co-finance. Lacking viable enterprises capable of offering market-based employment in rural areas, municipalities become the key agents for realizing state ambitions of a new form of workfare, i.e. preconditioning welfare with work.

The START program was initiated by the Fidesz government to fully finance public work projects to multiple disadvantaged regions [halmozottan hátrányos régiók] with unemployment rates above 14\%. These opportunities cannot be simply applied for on the basis of some kind of given normative standard. Municipalities have to actively create viable programmes for the employment of people they ask state funding for. However, not even these regions receive support corresponding to the number of unemployed people. According to Cseres-Gergely and Molnár (2014), only 10\% of those on public work find market-based employment after public work. The participants in the most optimistic cases could circulate between short term START work and social security payments [foglalkoztatást helyettesítö támogatás].

In 2014, the public work wage [közfoglalkozatási bér] was 77,300 Forints (205 euro) brutto, leaving 50,630 Forints (164 euro) after taxes. Those with higher qualifications are entitled to a higher payment. This wage is higher than social security payments (from 2012 called foglalkoztatást helyettesítő támogatás), which is, as of 2014, 22,800 Ft (74 euro). Public work wages constitute 78\% of the minimum wage, which is 101500 forints (328 euro) gross and 66,480 Forints (215 euro) nett. Public work provides highly precarious life conditions, since the provided work is typically short-term (5.1 months on average) (Cseres-Gergely and Molnár 2014). In 2013, $49.5 \%$ of public workers were employed within START programmes, $30.6 \%$ on long-term public work and $20.2 \%$ on national public work programmes. Further restrictions have been implemented since 2015 , which have taken away the obligation for municipalities to pay social security benefits.

Welfare states emerged in developed societies to combat the adverse effects of the market leading to social inequalities. From the seventies we witness a conservative and neoliberal turn towards workfare societies (Standing 2011). Those in poverty are made all the more responsible for their marginalization and universal rights to basic needs are replaced by moralizing means tested limitations on eligibility. While centrally distributed resources decline, the agency and responsibility of local welfare states for the provision of welfare increases. In Hungary the institution of public work gained a widening importance as an instrument to mediate eligibility to welfare transfers. Public work projects vary depending on the underlying attitudes of municipal power holders to the long-term unemployed and the institution of public work. The institution of public work is widely criticized (Asztalos Morell 2014, Köllő-Scharle 2011). However, while, conservative, and even racifing narratives have surfaced in relation to public work (see the Érmellék model), innovative and progressive narratives are gaining wider recognition. 


\section{LOCAL AGENTS OF CHANGE: INNOVATIVE UTILIZATIONS OF PUBLIC WORK}

Recently, different types of agricultural activities have spread as a form of utilizing public workers. However, the provision of work is only one motivation for municipalities to engage with food projects using public work. Another important motivation to introduce these agricultural projects based on public work for the municipalities is to increase their food sovereignty in the provision of food for their institutions (Asztalos Morell 2015b). Without doubt, municipalities have to act on behalf of different marginalized groups (such as the elderly, children or local entrepreneurs) and guarantee the functioning of their own institutions. These interests are not by necessity in harmony with the municipalities' responsibility to work for the welfare of marginalized groups. Progressive municipality leaders promote agricultural public work projects also in the hope of transferring know-how to public workers that the latter could use for cultivation in their own households and so increase their food-sovereignty (Asztalos Morell 2014). The degree to which public work based social farming projects lead to the transfer of agricultural production technologies and know-how in general still needs to be studied.

In Hungary municipalities have the responsibility to provide welfare. Most welfare transfers are means tested. Since 2015 the authority of municipalities to decide on which kind of social benefits are to be provided has increased. Public work is a construction that associates state support for the long-term unemployed with the responsibility to participate in work judged as societally beneficial. Resources to cover expenses of public work are to be accessed by municipalities through project applications to state funds. With the exception of START programmes, municipalities have to cover a smaller part (5-20\%) of the costs of labour. Thus, the active agency of the municipalities is assumed. Therefore, the provision of welfare differs greatly from one municipality to the other (Asztalos Morell 2015a, b). Moral communities of rural elite are seen to obtain power to formulate norms defining deserving and undeserving poor (Thelen et al. 2011, Schwarcz 2012). Municipalities become the institutions of redistributing scarce resources of social benefits, and by which act typically as top down organizations.

\section{CIVIL SOCIETY AS COUNTERFORCE OF LOCAL DEVELOPMENT}

The importance of civil society increased in the functioning of local welfare regimes in the new models of governance. Soviet-type systems aggravated the condition for bottom-up, empowering civil organizing (Rose 1999). The destruction of the foundations of systems of public organization in Soviet-type systems left longlasting effects, not the least for agrarian development in the region as Svendsen-Svendsen's (2004) comparative study of cooperation in Poland and Denmark indicated.

The so-called NGO-isation thesis for the rise of CEE civil society emphasized the importance of external funding and ideation. However, recently the NGO-isation thesis has been criticized (Jacobsson-Saxonberg 2013, Asztalos Morell 2015c). Jacobsson and Saxonberg (2013) argue that a broader definition of civil society is needed for CEE that includes both formal and informal organizations. Using this broader definition reveals a multitude of civil movements. 
State involvement with civil movements larger in CEE compared to the developed world (Fábián 2009). Csongor and Lukács (2003) comprehensive study of labour market projects for Romani indicate that while the overwhelming majority of financing such projects originates from diverse state sources, such as regional development funds, the Ministry of Social Welfare, the Labour Relations Centre, the National Development Fund and civil organizations, as well as the Romani Minority Self-governments (RMS) (Molnár-Schafft 2003), all played an active part in facilitating project applications that allowed for the utilization of these funds.

The most marginalized communities such as the Romani typically lack elites on the local level (Vajda and Dupcsik, 2008), or if there are such elites they might distinguish themselves from the poor, and projects aiming to empower communities do not reach those in need (Molnár-Dupcsik 2008) and are organized in a top down fashion (Asztalos Morell 2015d). Civil society projects focusing on individualized solutions, such as "Minden gyerek lakjon jól" [Every child should be fed!] fighting poverty have been criticised. Ladányi and Szelényi (2003) argued that such efforts are doomed to fail since the causes of poverty are partly structural and partly ideational. A culture of poverty combined with long-term multi-generational exclusion create immediate needs which are difficult to brake. In Csetenye social food/land projects failed to create sustainable changes, due to the immediate needs of the participants.

Even if there are also examples of successful development projects with focus on local capacity building and community development (Asztalos Morell 2015e, Szinesgyöngyök), short-term projects seldom result in sustainable improvements. The degree to which civil organizations contribute to local capacity building and bottom up implementation requires further research.

\section{EMPOWERMENT, AGENCY AND ASSET BASED COMMUNITY DEVELOPMENT}

As a critique of the predominant needs based approach to counteract marginalization Kretzmann and McKnight (1993) developed the model of ABCD (Asset Based Community Development). The critique argued that governmental and donor agencies focusing on needs assessments reproduce the image of marginalized groups as needy and reinforce their status as clients, focus on the amount of aid the community have attracted (focus on external institutions) rather than on groups within the communities: "denies the basic community wisdom which regards problems as tightly intertwined, as symptoms in fact of the breakdown of the community's own problem solving capacities" (4) Kretzman and McKnight (1993) promoted as an alternative approach to enhance local people's and their association's capacities to build powerful communities from within. Community members are to identify new perspectives through which they are enabled to "begin to assemble their strengths into new combinations, new structures of opportunity, new sources of income and control, and new possibilities for production" (6). This process led by transforming the relation between municipal agencies and neighbourhoods from perceiving the latter as "consumers" of services to seeing these as "designers" of programmes and finally as "producers" of communities (Moore-Puntenney 1999, Mathie-Cunningham 2003: 476). Thus, $A B C D$ promotes a new type of relation between donor organizations/municipalities and recipients of aid. Rather than viewing these as individuals, it emphasizes the importance of communities/neighbourhoods, while it sets the focus on the capacities of the latter, communities are encouraged at the outset to 
"build an inventory of their assets and are encouraged to see value in resources that would otherwise have been ignored, unrealized, or dismissed." Such unrealized resources could be "personal attributes and skills ... the relationships among people through social, kinship, or associational networks." (Mathie-Cunningham 2003: 476). Formal institutional resources can be activated by mobilizing these informal resources. These could act as facilitators for the identification of needs and resources that can enable the mobilization of additional support, i.e. the facilitation of positive synergies.

Thus, following the argument above, the goal of community development should be solidarity and agency. Its methods ought to be self-help (making use of agency, mobilizing people's assets), be based on felt needs resisting developmental imposition, and they are to facilitate participation (i.e. taking part in the production of collective meanings opposite to the exclusionary practices of the production collective meanings in modern societies). "The principle of participation means inclusion, not merely in the electoral process or endorsing decisions but in deciding the agenda for debate and decisions; it means inclusion in the processes of defining the problems to be solved and how to solve them." (Bhattacharyya 2004: 23)

\section{RESEARCH AGENDA AND METHODS}

As part of my research project supported by the Swedish Research Council [Vetenskapsrådet] Negotiating poverty I studied public work projects with a focus on municipality organization of social agricultural projects in five disadvantaged rural communities in North-Eastern Hungary. In parallel with this I also studied civil society projects to combat poverty. In this paper I focus on municipalities that developed collaboration with a civil society initiated project: PROLECSO. ${ }^{7}$ This initiative is unique in its approach to focus on community development as part of its developmental goals. I have studied the efforts of PROLECSO through different data and methods. They have a sizeable media foot-print both in formal and social media. I conducted interviews with the initiator of PROLECSO Melinda Kassai, local leaders of PROLECSO, Zsuzsanna Lengyel and István Bárdos, as well as with municipal facilitators of collaboration with PROLECSO, among these 2 mayors participating in collaboration with PROLECSO. My project assistant and I have participated in three community events where we acquainted ourselves with participants in the project. These occasions allowed for further discussion with additional mayors involved in a developing small regional collaboration involving relations with PROLECSO. My project assistant and I have also analysed the data-collection conducted by PROLECSO prior to launching a Norwegian Foundation project involving 8 municipalities for PROLECSO. These latter data are not included in this analysis. The research data analysed in this paper was collected between 2013 and 2015. The two communities in the focus of the current analysis contain a sizeable Roma minority, which nonetheless is below 20\%. Hejőkeresztúr has 1025. Out of its 656 active age citizens there were 40 persons receiving unemployed social benefit tied to a minimum of 30 days' work during the past day [bérpótló támogatás]. Hejőkeresztúr has had a nation-wide renowned progressive leadership working for multicultural society for the past years and has adapted the so called Stanford educational model to the local circumstances. ${ }^{8}$ This is not surprising given that the municipality is also engaged with socially integrative programmes on a broader scale. One aspect of this engagement is the collaboration with PROLECSO.

7 http://www.bffd.hu/pro-rataouille-program/hejo-sajo-village-network

8 http://www.h2oktatas.hu/hu/szuelknek/63-a-hejkereszturi-altalanos-iskola-tanitasi-modellje 
Bükkaranyos has 1478 inhabitants with an unemployment rate of 10\%. Here the municipality won a social land programme Szociális Földprogram 2012 project. They bought machines, a foil greenhouse and utilities necessary for the cultivation from the HUF 1,500,000. They are to start with the programme in the school garden utilizing public work projects. The production is to supply the food provision for the school.

\section{TWO APPROACHES TO SOCIAL AGRICULTURE}

In the following I compare two models of social farming, both intending to improve the conditions of long-term unemployed people, living under the poverty level using ecological farming. Both municipality driven use of agricultural land and alternative, civil society initiative based projects share the interest to utilize uncultivated land and view that as enriching the community at large. Due to the growing amount of uncultivated land, these become reliability rather than resources. Lajos Nagy, the mayor of Bükkaranyos argues that taking unused land under cultivation releases those, mostly elderly, residents from the responsibility to weed the land, who otherwise have to pay someone to clear the land. Instead, the municipality contracts these units for long-term use, which can provide some income for these elderly:

"Municipality has long-term tenancy with small land-owners of plots; the municipality removes the plot owners' responsibility to clear the land of weeds" (Nagy)

Also, community members spent their incomes outside the community on products they could produce as a local resource. By this they spend resources outside the community that could be used for the benefit of the inhabitants. As Melinda Kassai of Pro-Lecso argues:

"For some two decades people pass their own and the municipality's land daily, and go to the local shop, or to the Spar, or X or Y and they buy that... they even get into a car and drive to a shopping centre. These things become more expensive, compared to what it costs if someone starts to produce on his/her own land, and garden. They do not even need land." (Kassai)

However, beside similarities, municipality utilization with the employment of public workers and civil society approaches differ both in their economic rationality and social dynamics.

\section{MOTIVATIONS FOR MUNICIPALITY DRIVEN SOCIAL AGRICULTURE}

One key motivation for the initiation of municipality driven cultivation named by the mayor of Bükkaranyos was the above discussed urgency to turn fallow mark into cultivation. Nagy argues for the benefits of employing public workers for the reconditioning of uncultivated units. In Bükkaranyos the municipality reconditions the mark using public workers:

"Owners can expect rent only after restoring the land's productivity. This was achieved by public workers. The ownership relations, papers of the land had to be cleared, Out of 20 hectares of uncultivated land in the process 8 hectares became ready for cultivation last year. $200 \mathrm{~m}^{2}$ is covered by foil greenhouses. Some hectares are utilized for fruit plantation." (Nagy)

The Bükkaranyos municipality utilized the land and cultivates for the use of the municipality institutions, such as the municipality pantry servicing the local school, daycare and elderly home care (18 persons): 
"It will result in cost-reduction, and surely, a bio production, vegetables growing under controlled conditions would result in healthy vegetables for the elderly and children"

Thus, the mayor was primarily concerned with the health-promoting effects of bio produced food, where engagement with bio production locally allows the municipality to control the conditions under which production is carried out. An important aspect emphasized is also the reduction of expenditures that the municipality has to spend on food provision in its institutions. Concerning the participants in the programme the mayor is mostly hoping that the public workers would learn from technologies and feel encouraged to produce in their own gardens.

A few alternative strategies were documented to increase the self-motivation of participants in the public work based social land programme. In some municipalities those participating in public work social agriculture programmes can consume the products on the production sites (Asztalos Morell 2015b) and in other cases surplus products are distributed either among the needy in the community or to all inhabitants (Asztalos Morell 2014a). Thus, mayors use the option of distributing products of social agriculture utilizing public work for combating rural food poverty in different forms and degrees.

\section{PUBLIC WORK AS LABOUR RELATION}

Those, engaged with the production are in a public work relation to the municipality, and as such are in a dependency relation to the municipality. Due to this dependency relation, this labour force is lacking selfmotivation as well as skills. Therefore, supervision is required:

"It is difficult to keep 60-70 people [in the public work programme] in motion, to supervise and monitor their work in a way that their work should produce values is a difficult task. The intention is to choose brigade and group leaders from those working as public workers in return for higher remuneration. But they do not accept leaders chosen from their own ranks. It is not working. I need municipal employees for this task. But to monitor 4-5 areas, to have continuous control, we do not have enough people for that." (Nagy)

Thus, supervision needs to be provided by regular municipal skilled employees. The expenses of such employees are normally not covered by the resources that municipalities receive for public work projects (Asztalos Morell 2015b). Thus, public work is a work relation with built-in problems.

\section{SOCIO-ECONOMIC RATIONALITY BEHIND PUBLIC WORK BASED SOCIAL AGRICULTURE}

The mayor in Bükkaranyos municipality finds municipal engagement with public labour based social agriculture ambiguous from its broader societal utility beyond the needs of finding productive employment for the long-term unemployed. He is questioning, whether the engagement with production should be the primary goal of municipalities:

"It should not be the task of the municipality to produce. I mean, this is not a co-operative, not an agricultural company, or other company." (Nagy) 
He argues that his municipality is engaged with social agriculture due to the lack of market based alternatives to the employment of public workers, while municipalities need to fulfil their social obligations to longterm unemployed residents. However, it is questionable, whether in purely economic terms, the municipality supported social agriculture is the most effective way to produce:

"The most effective would be, if the local enterprises, and producers [östermelök] would receive outlocalized public workers [to work in their production units]. Since he is a productive company, he has to pay taxes. If he employs that person, it also has consequences for taxes. The value is increasing, that he is generating, and he sells that, than the industrial taxes generated flow into the municipality budget. This would be an expansion for us." (Nagy)

Thus out-localizing public workers to private, market-oriented agents would boost private ventures and indirectly increase tax revenues for the municipality. Another economic concern was that municipalities do not have as a main function to cultivate land. They lack both material resources, such as up-to-date equipment and immaterial resources, such as know-how. In order to be able to engage with production, municipalities need to make major investments into production technologies:

"We have to start everything from zero. I have a higher investment expense to start any kind of programme. On the other side there are five, who already have foil greenhouses, they have the watering pipes. They do have the tractors. They do not have to buy those. One can place 2-3 persons to his side who would help him to produce. That way he could produce much more. The price to produce per unit would be much lower. ....those people are experts, they are competent within the given area." (Nagy)

All an all, he argues that from a societal perspective supporting private producers with out-localization of public workers would be more efficient:

"It is going to cost us a lot to achieve a self-supporting state" "It would be better to help the prevailing enterprises with these opportunities" (Nagy)

The mayor names, among advantages of municipality based social farming compared to out-localization that the latter is difficult to supervise: "Of course it would be more difficult to control." Another argument for municipality driven social agriculture is that this activity is creating socially and economically useful products compared to other commonly performed public work tasks:

"It is definitely an advantage to carry out value producing labour. It is definitely better than the previous practice, when one could practically only utilize public work for communal and settlement maintenance tasks." (Nagy)

\section{ADVERSE EFFECTS ON COMMUNITY COHESION OF MUNICIPALITY DRIVEN CULTIVATION}

Looking at the impact of public work based municipal social agriculture projects on community cohesion, the mayor highlights how this institution can create internal contradictions and conflicts of interest. The municipality, by actively supporting the production and utilization of products in its institutions decreases its economic support for small producers [östermelö] who are potential food/suppliers for municipal institutions. The economic interests of these collide with the interests of those long-term unemployed benefiting from the programmes: 
The volume [supplied by municipal production] falls below public procurement [közbeszerzés]. There is a requirement for tenders of public institutions. Our real problem is that we have many small scale private producers [őstermelö] in the settlement. Prior to his, we bought a lot of products from them, in order to help them. With this program we created a competition for them, since, what we produce on our own, I am not going to buy from him.

The interest of these private producers' conflicts with the interests of providing meaningful employment for the long-term unemployed: "On the other hand I secure the employment of 30-40 people". Thus, municipalities need to balance the interests of groups with different degrees of vulnerabilities.

I found alternative strategy followed by another mayor to balance similar conflicts. On the one hand, in agreement with those participating in the municipality driven social agriculture, the mayor decided to distribute surplus products equally to all residents in the municipality (Asztalos Morell 2014a). On the other hand this other mayor promoted private producers by alternative project-based support forms. As one example he gave start-up support for commercial cucumber producers. Both strategies counterworked unintended, yet in practice polarizing side-effects of public work based projects.

\section{PROLECSO: AN EXAMPLE OF COMMUNITY DEVELOPMENT BASED SOCIAL AGRICULTURE}

PROLECSO Association supports civil society based developmental projects. It realizes a unique co-operation between different agents on a win-win basis. The initiating civil organization, the Pro-Cserehát Egyesület designed the developmental concept. The civil organization is partly supported by private donations from first of all the ERSTE Foundation and state support in 2012 and 2013. Projects are realized in collaboration with local municipalities. It aims to combine the goals of ecological, social and economic sustainability in a complex way. It is to create a bio-diversity based, socially sensible forms of production. Bio-diversity based ecological production provides healthy, chemical free products for both the producers and for potential target groups functioning as markets for the products. Awareness of the importance of such products for health is growing.

PROLECSO addresses social sustainability in a multifaceted way. Its major target group are marginalized settlements with long-term unemployment, isolated from major markets and work opportunities. It also aims to challenge prejudices and ethnicity based divisions. Thus, beyond individual benefits for participants with economic hardships it targets the development of communities both as a goal in itself and as a means for the realization of the project:

"In this impoverished world people live isolated, as in a cocoon. The programme provides the opportunity to develop a community from them, to organize a community" (Lengyelné).

Another central ingredient for achieving social sustainability is the emphasis on individual motivation in an individual pursuit of happiness and self-sufficiency. This is juxtaposed by the workings of social benefit systems based on passive transfers, which reward idleness. Participation in the project is part of the reward.

One could interpret the advantages of participation by applying Bourdieu's (1986) theory of immaterial capital assets. Participants obtain valuable human capital (know-how of ecological farming), cultural capital 
(internalizing and developing new value and relational patterns), social capital (contacts with fellow-participants, potential marketing contacts, contacts with experts and appreciation of the political leaders of the municipality) ${ }^{9}$ as well as enjoy economic benefits (supply of resources, production means as well as the yields of the production).

Criticism of state supported adult training programmes argues that participants in such programmes typically lead to skills that later seldom lead to work opportunities. Although participants obtain monthly payments during the period of training, they are often not motivated, since they are not expecting to find employment afterwards. In contrast, PROLECSO participants do not receive direct payments. Rather, concrete material rewards can first be realized when the cultivated products start to yield. The immaterial benefits, as discussed above, that participation yields are difficult to measure in monetary terms. Furthermore, the benefits of participation ought to be counted in a broader context. Meaningful activity, healthy food and life style as parts of an improved standard of living contribute indirectly to better health, decrease in social tension and consequently to reduced societal expenses in the long-term.

The concept of economic sustainability is derived from Yunus' (2010) social business concept. While Yunus is not directly against profit at large, he argues against profits made at the expense of the most marginalized groups. Those in extreme poverty are extra vulnerable since they have no means to resist forms of extreme exploitation, let it be in terms of work conditions or extra profit on loans. Social business would be based on the mobilization of people's capabilities and inner motivation. Such activities can and favourably should lead to economically sustainable production either in the form of subsistence production or market production. However, at the initiation stage, the projects receive subventions originating from diverse resources, including the inputs of the civil organization, which originates both from state support and from private donations and from the municipality. Thus, seen from a strict market rationality principle, the project is not sustainable. However, its sustainability is to be seen from a more complex economic and social rationality principle.

The pedagogical concept of PROLECSO, inspired by Yunus relies on two major principles. Firstly, they are based on continual, informal education. Rather than transferring skills in a formal context, they establish an ongoing contact with the participants following the whole process of production to consumption and sales.

Secondly, the programme's goal is to organize communities, to build communities: An important element is participation based empowerment [képessé tevés]. Empowerment is fostered by regular participation, development of responsibility and internal control, instead of constant supervision, happiness and pride related to activity where producers are involved in the decision making process, realization of advantages of collaboration, learning to participate in planning. Finally, this involvement also strengthens the opportunity to work for a future concept ${ }^{10}$.

9 On social capital see even Putnam (2000). 


\section{LAUNCHING PROLECSO}

PROLECSO has been initiated in Hejőkeresztúr, a municipality with a municipal leadership welcoming their intentions to introduce social farming with community development as part of the goals. The municipality contributed land. The municipality engaged public workers to recondition uncultivated land. The main site of production is this area. PROLECSO is also supplying complex cultivation support, including seeds and equipment.

One of the principles of PROLECSO is that those charged with training have to come from inside the community:

"The person has to come from within, simply need to know the local conditions, know how to relate to the people, how issues need to be settled. Does not have to be a person with university training... but the person have to be agile, prompt." (Kassai)

The leader of the project in Hejőkeresztúr is Zsuzsanna Lengyel. She has agricultural training and is of Roma origin from the vicinity. She has been active in the recruitment of participants. The cultivation was combined with an educational program. Learning by doing is a key pedagogic principle. This method has advantages, since there are some among the participants who are functional illiterates. Meanwhile, there are even some middle-aged participants, who come from economically better established families with their own gardening facilities, who were attracted to the project due to the new know-how of bio farming offered. To establish equity, labour inputs are carefully recorded. Reward from the yield is divided in relation to the work contribution. Beyond cultivation a mutual help scheme has developed. In one case an elderly woman needed help with moving a fridge. At first it was difficult to find someone who would help. But, with the help of the labour exchange scheme participants became more open to assist each other.

\section{SOCIAL ASPECTS OF COMMUNITY BUILDING}

Municipality H-K has been welcoming to co-operative with PROLECSO with focus on community building. This municipality has been appreciative to the importance of community building even in its educational model applying a Stanford University based integrative pedagogic approach. The municipality engaged a process facilitator, who is collaborating with PROLECSO in community building aspects of the civil organization based social agricultural initiative. Bárdos, the facilitator of community building efforts started with identifying vulnerable groups within the municipality. The chief principle was to overcome cleavages along age, class and ethnicity lines:

"We try to improve the position of the elderly. One claims that alienation characterizes urban settlements. This has reached even us... We try to reduce their feeling of loneliness. But also we try to help them with things they cannot do." (Bárdos)

Meanwhile, the younger generation, having other forms of vulnerabilities, such as lacking employment, do have resources, that could benefit these older people. In order to initiate bonds in the community they want to mobilize civil engagement: 
"We want to activate volunteer work. We would like to couple the elderly with the younger. ... and the turning of the younger towards the elderly is starting to work." (Bárdos)

The introduction of bio cultivation in collaboration with PROLECSO is an additional step in this direction. Bio cultivation is both a cheaper way to produce (avoiding high chemical expenditures) and a way of production that creates healthier produce. Creating opportunity to learn about and engage with bio cultivation creates an interest to participate, even among local producers. It can unify the interests of people in a vulnerable situation living in food poverty and with no previous know-how about agriculture and people who have been involved with household based production through their whole life. These linkages might emerge between long-term unemployed youth without material resources on the one hand and elderly with land, yet no physical ability to cultivate it.

PROLECSO also supports cultivation on the household lots of participants. Seeds are provided and equipment can be borrowed. Members of PROLECSO project are encouraged to help each other on the household lots. Such help is also recorded in the labour exchange scheme. Those participating obtain reimbursement in produce or in money after sold produce, in proportion to their labour input into the common lot. Participants cultivate, as well as on this common lot also on their own private lots.

An additional community building method is the initiation of different community celebrations. Such events also contribute to get popularity for the project in the broader settlement and beyond.

\section{ECONOMIC MODEL FOR PROLECSO}

PROLECSO is to build on the autonomous agency of its members. One motivation for this originates from the use of produce. The major goal is to produce food for own consumption. In the project participants can consume the products in relation to their work input into the cultivation. The value of the consumed food is estimated to contribute with up to 20,000 Forints a month from a land of $200 \mathrm{~m}^{2}$, which is to be seen as a substantial contribution to households living from incomes below the poverty level (Kassai).

Beyond own consumption, participants are encouraged to sell on local markets, however, this might be hindered due to tax regulations (see below). The civil organization is engaged with developing a marketing strategy, where local producers would come into direct contact with urban consumers. Thus local and urban synergies could emerge.

Beyond the material benefits (consumed food and income from sales) participation contributes to the improvement of cultural capital (through training received in the form of cultivation and consumption knowhow) as well as social capital. The latter is manifested both as an expanded social network cutting across different social segments of the community increasing the "trust capital" of participants. It also provided viable networks of assistance, and organization of production. Participating in joint, civil society projects creates a valuable asset in combating marginalization. At last, producing and consuming healthy food becomes embodied in a better diet and as a consequence better health. 


\section{POTENTIAL SYNERGIES CREATED BY MUNICIPAL COLLABORATION WITH PROLECSO AS A SOLUTION TO DILEMMAS}

As discussed earlier, the mayor of Bükkaranyos indicated several disadvantages associated with using public work based social land programmes. The concerns were the lacking self-motivation of participants and the social tension resulting from replacing municipal purchasing of food from local producers by public work production. The mayor indicated the presence of a latent conflict between local producers [östermelök] and the interests of the long-term unemployed. Mayor Lajos Nagy found a solution for these dilemmas by developing a collaboration with PROLECSO. He aimed to increase the conscientiousness of public workers. The municipality contacted the Pro-Cserehát Association, which had started to work in the region, in Hejőkeresztúr, the year before. Pro-Cserehát provided bio-economic education for the participants. In parallel, the association succeeded in obtaining funding for the extension of its activities to Bükkaranyos. With the help of this support they could raise an additional foil greenhouse. They added an additional hectare for open field cultivation. The municipality aimed to primarily help the unemployed to produce for their families. The public work programme could provide work for 10 persons through 9 months. PROLECSO had a more inclusive approach: "Anybody could participate in their programme, called PROLECSO, who wanted to learn bio-cultivation and wanted to produce for their own consumption or for sale." (Nagy) Thanks to the opportunity an additional 12 voluntary participants joined. PROLECSO became a partner providing a joint educational programme and an assistant. According to the mayor the collaboration not only helped to re-cultivate an abandoned area. The greatest achievement for the mayor was "to see people of totally different age, know-how and economic conditions work together voluntarily and in agreement."

PROLECSO could unite the interests of diverse groups, by spreading know-how of bio cultivation and by working for the creation of markets for the locally produced goods that would incorporate all three types of producers (public work based municipality coordinated social agriculture, private farming and PROLECSO project participants):

"Difficult to create a healthy balance. That was one reason why we also brought the PROLECSO program into this equation. It was to help with the marketing outwards. In order to save their [östermelö] markets also, and eventually contribute to its expansion. Since even those vegetable and fruit producers could participate in the marketing who otherwise produce as small scale private farmers [östermelö]." (Nagy)

PROLECSO aims to encourage participants to market their surplus. This, however, is hindered by regulations that give advantages to so called "őstermelo". This tax elimination benefiting the "őstermelo" was to ease the possibility to market the surplus produce of those, who cultivate as a side-activity on their households beside employment. However, benefiting from this construction assumes employment status:

"Marketing is hindered due to contradictory regulations. A small scale private producer [östermelö] can only be a person who has employment. These producers are exempted from taxes up to 600,000 Ft annual sales. This excludes those who do not have a job, and so the strata that is most in need of it. If one does not have a job, one has to pay tax. But one is impoverished just because one does not have a job. These people cannot go and sell on the open market. People in the programme help each other out. Those who have the "östermelo"" title sell for the others. Some are on public work, and these can sell. But this type of employment is commonly short (3-4 months)." (Lengyel) 
Therefore, the fact that PROLECSO is composed of participants from varied backgrounds, that include even people with some form of employment, enhances the opportunities to sell some surplus products. Nonetheless, in the long-run, PROLECSO plans to establish some non-profit and/or fair trade type marketing organization of its own to enhance the possibility of selling their products on markets.

The collaboration between municipalities and PROLECSO also facilitated the joint organization of knowhow transfer. The launching of bio production had expanded to eight municipalities by 2015 with the help of a Norwegian Civil Foundation support grant. When these municipalities showed readiness to encounter collaboration with PROLECSO and launch bio production the common platform created openings for potential visibility and impact on a broader regional and hopefully national level. The first PROLECSO market has launched not only the products of PROLECSO units in these eight neighbouring municipalities but also private producers in the area. Community building efforts of PROLECSO aiming to integrate marginalized groups and improve their living conditions becomes a facilitator and collaborator with municipal efforts to combat marginalization in their region. The alliance built between these municipalities serves also as a forum for the dissemination of progressive ideas pointing beyond emphasis of individual responsibility for poverty.

\section{CONCLUSIONS}

At the beginning of this paper I argued along comparative research on poverty, that food poverty is one of the most central aspects of poverty. People resort to the reduction of food and nutrition when other expenses (such as expenses related to housing and utilities) cannot be kept up. Nutritional deprivation is higher among families with children. Nutrition and health standards are closely related to each-other. Therefore, combating food poverty is of utmost importance. Under conditions of prolonged austerity measures related to conservative and neoliberal welfare/workfare regimes and long-term lack of work opportunities offered to low-skill populations, monetary transfers are unlikely boots of persistent poverty. Within the limitations of the conservative workfare paradigm municipality organized public work based social agriculture projects seem to open a channel of relief for food poverty under the leadership of socially innovative municipalities. Such initiatives so far have primarily been used to improve the supply of food for municipal institutions. However, indirectly, by permitted on site consumption, as well as by the possible dissemination of cultivation know-how and access to seeds and plants, participation in such public work projects opens the possibility for further benefits.

Nonetheless, the pitfalls of public work based social agricultural projects were also highlighted. Such social agricultural programmes can contribute to the re-integration of the long-term unemployed into short-term work projects. However, labour remains subject to disciplinary and supervisory measures. Economic benefits seem to favour the municipality, where produce is channelled into the consumption in the municipal institutions. The production is more viable compared to other activities, since it uses fallow mark and creates local products where the quality of products is under the control of the participants. But due to the necessary investments the mayor estimated that it could be economically more feasible to support already established market producers to employ long-term unemployed people. However, in this form fewer workers would be needed, and those without employment would still need to be integrated into meaningful activity. Further- 
more, the active support of the municipality of non-market based social production creates competition with market based producers and reduces their market, which in turn increases social tension between the groups. The distribution of produced food according to different principles (to those working as public workers, other needy in the own municipality, to all residents in the own municipality, or even to needy outside the own municipality) have shown in other municipalities proved either to strengthen support to the needy or to work for diminishing polarization within the municipality.

In comparison, the PROLECSO concept urges win-win situations, where small scale private producers [östermelö] and unemployed can find joint interest. This is in the dissemination of ecological production, and work for market for these products. PROLECSO aims to enable the participants to work autonomously and of own interest and agency. The motivation of participating PROLECSO members increased due to the applied method of reward, as well as due to the positive impact of the community building effort. Although capacity building is achieved through know-how transfer, part of this know-how is vested in the building of community and own responsibility.

While the two organisations have different motivation, goals and means to implement social farming, they have both some common objectives, such as the utilization of land, transfer of know-how, improvement of the living conditions of long-term unemployed. Furthermore, it appears that collaboration between the two has also synergistic effects. Sharing know-how dissemination, access to required technology and land are those aspects that can offer mutually beneficial exchange. Furthermore, community development is also a viable asset for the municipality, even if the methods differ in the two organisations: the municipality focuses on the group of public workers, thus applies a top-down and segregating model, inherent in public work as a work organization form. Since the products generated in the public work projects replace the products previously purchased from local producers, public work projects create unintentional conflict and competition between producers and the unemployed. In contrast, the PROLECSO project focuses on a community building, integrative and bottom-up model combining the interests of different social groups. Nonetheless, the general status increment that PROLECSO and the municipality achieved for the two different social food projects seems to have a positive impact on the evaluation of public work and public workers engaged with food production. Public workers contributed to the reconditioning of land, learning bio cultivation. The status of their work was raised. This positive impact was manifested in the generation of common actions. Such common action was the organization of a joint food market, where PROLECSO and municipalities participating in the PROLECSO project jointly sold and presented their products inviting other producers from their communities to participate.

Reflecting on the theoretical trust of $A B C D$ approach, some key elements of the community based approach seem to come to the surface in the synergies between the two projects. PROLECSO, and even participating progressive municipalities view long-term unemployment not as a matter of individual behaviour, but rather as a consequence of a lack of alternatives. They see the solution in collective approaches, for which public work appears under the prevailing workfare regime as one potential vehicle. However, community building per se is not the primary goal of public work projects, neither is the content of such projects constructed from below built on the "inventory of assets" of and self-proclaimed goals of community members. Top down elements of 
organization are present even in PROLECSO's development methods. Nonetheless, PROLECSO works consciously on a broad agenda of developing the capacities of participants as members of communities. The creation of selfhelping, collaborating communities is the first stage in releasing autonomous self-defining powers. 


\section{REFERENCES}

Asztalos Morell, I. (1999) Emancipations Dead-End Roads? Studies in the formation and development of the Hungarian Model for Agriculture and Gender (1956-1989). Uppsala: Acta Uppsaliensis, 46.

Asztalos Morell, I. (2014) Workfare with a human face? Innovative utilizations of public work in rural municipalities in Hungary. Metszetek, 3 (4) 1-22. http://dx.doi.org/10.18392/metsz/2014/4/1.

Asztalos Morell, I. (2015a) On the Roma precarious experience facing Pentecostalism. Della Porta, D. - Hänninen, S. - Siisiäinen, M. Silvasti, T. (eds.) The New Social Division: Making and Unmaking Precariousness. Palgrave Studies in European Political Sociology, Basingstoke: Palgrave MacMillan, 139-157.

Asztalos Morell, I. (2015b forthcoming) Beneficiaries and anomalies of innovative municipal public work projects in Hungary. Acta Uppsaliensis Uppsala Yearbook of Eurasian Studies. London: Wildy, Simmonds \& Hill Publishing.

Asztalos Morell, I. (2015c) An intersectional analysis on Women Roma NGOs in Hungary. Baltic Worlds, 8 (3-4): 35-46. http://balticworlds.com/gender-equality/?s=Asztalos\%20Morell.

Asztalos Morell, I. (2015d) Can Renewable Energy Contribute to Poverty Reduction? A Case Study on Romafa, a Hungarian LEADER. In Granberg, L. - Andersson, K. - Kovách, I. (eds.) Evaluating the European Approach to Rural Development Grass-roots Experiences of the LEADER Programme. London: Ashgate, 183-206.

Asztalos Morell, I. (2015e) Voicing Roma women: Intersecting marginalities and social entrepreneurship of Roma women's NGOs in Hungary. In Gradskova, Y. - Sanders, S. (eds) Institutionalizing Gender Equality - a Critical Approach from a Global Perspective. London: Lexington Books at Rowman and Littlefield, 149-171.

Bhattacharyya, J. (2004) Theorizing Community Development. Journal of the Community Development society 34 (2), 5-34. http://dx.doi.org/10.1080/15575330409490110.

Béres, T. - Lukács, Gy. (2008) Kamatos pénz a Csereháton. Magyar Valóság. Esély, 5: 71-97.

Bourdieu, P. (1986) The forms of capital. In Richardson, J. C. (ed.) Handbook of Theory and Research for the Sociology of Education. New York: Greenwood Press, 241-248. http://dx.doi.org/10.1002/9780470755679.ch15.

Clasen, J. - Clegg, D. (2011) Regulating the risk of unemployment: national adaptations to post-industrial labour markets in Europe. Oxford: Oxford University Press.

Cseres-Gergely, Zs. - Molnár, Gy. (2013) Közfoglalkoztatás, segélyezés, elsődleges és másodlagos munkaerőpiac [Public work, social aid and secondary labour market]. In Kolosi, T. -Tóth, I. Gy. (ed.) Társadalmi riport. Budapest: TÁRKI, 2014, 204-224.

Csoba, J. (2014) A közfoglalkoztatás régi és új rendszere. Útközben az 'Út a munkához' programban. (The new and old system of public work. On the way in the "on the road to work" program). Esély, 1, 4-24.

Csongor A. - Lukács Gy. (eds.) (2003) Roma munkaerőpiaci programok. Budapest, Autonómia Alapítvány.

EEA (European Environment Agency) (2005) Household Consumption and the Environement. Copenhagen: EEA Report Nr 11.

Fábián, K. (2009) Contemporary Women's Movements in Hungary: Globalization, Democracy, and Gender Equality. Washington D.C., Woodrow Wilson Center Press.

Fazekas, K. - Scharle, Á. (ed.) (2012) From pensions to public work: Hungarian employment policy from 1990 to 2010. National Employment Fund of Hungary, Budapest.

Gábos, A. - Szívós, P. - Tátrai, A. (2012) Szegénység és társadalmi kirekesztettség Magyarországon, 2000-2012. In Szivós, P. - Tóth, I. Gy. (ed.) Egyenlőtlenség és polarizálódás a magyar társadalomban. TÁRKI, Monitor jelentések: 37-57.

Giddens, A. (1984) The constitution of society: outline of the theory of structuration. Cambridge: Polity Press.

Jacobsson, K. - Saxonberg, S. (eds.) (2013) Beyond NGO-ization: The Development of Social Movements in Central and Eastern Europe. Burlington: Ashgate.

Junestav, M. (2004) Arbetslinjer i svensk socialpolitisk debatt och lagstiftning 1930-2001. Uppsala: Acta Universitatis Upsaliensis.

Kornai, J. (1980) Economics of Shortage. Amsterdam, Netherlands: North Holland.

Kovách, I. (1988) Termelök és vállalkozók. Budapest: MTA.

Kovách, I. (2010) A jelenkori magyar vidéki társadalom szerkezeti és hatalmi változásai. MTA doktori értekezés. MTA, Budapest.

Köllő, J. - Scharle, Á. (2011) A közcélú foglalkoztatás kibővülésének hatása a tartós munkanélküliségre [The impact of public work on long-term unemployment]. In Fazekas, K. - Kézdi, G. (eds.) Munkaeröpiaci tükör. Közelkép: Foglalkoztatáspolitikai programok hatásvizsgálata [Labour market mirror. Close-up: Effects of employement-political programs]. Budapest: MTA Közgazdaságtudományi Intézet, Országos Foglalkoztatási Közalapítvány, 145-160.

Kretzman, J. P. - McKnight, J. L. (1993) Building communities from the inside. Chicago: ACTA. 
KSH (2013) Gazdaságszerkezeti Összeírás. Available at: https://www.ksh.hu/docs/hun/xftp/idoszaki/gszo/gszo13.pdf [Accessed: 0201-2016].

KSH (2014) Élelmiszerek egy före jutó hazai fogyasztása, 1970-2013. Available at: http://www.ksh.hu/docs/hun/xstadat/xstadat_hosszu/elm14.html [Accessed: 22-11-2015].

Ladányi, J. - Szelényi, I. (2004) A kirekesztettség változó formái. Napvilág, Budapest.

Mathie, A. - Cunningham, G. (2003) From clients to citizens: Asset-based Community Development as a strategy for community-driven development. Development in Practice, 13(5) 474-486. http://dx.doi.org/10.1080/0961452032000125857.

Molnár, E. - Dupcsik, Cs. (2008) Country Report on Education: Hungary. Edumigrom, CEU, Budapest. Available at: http://www.romaeducationfund.hu/sites/default/files/documents/edumigrom_background_paper_hungary_educ.pdf [01-03-2016].

Moore, H. - Puntenney, D. (1999) Leading by stepping back: A guide for city officials building communities. Chicago: ACTA.

Molnár E. - Schafft, K. A. (2003) Social Exclusion, Ethnic Political Mobilization, and Roma Minority Self-Governance in Hungary. East Central Europe, Volume 30, Issue 1, 53-73. http://dx.doi.org/10.1163/187633003×00036.

MSH (Magyar Szegényellenes Hálózat) (2014) A közfoglalkoztatási csapda. A Magyar Szegényellenes Hálózat Jelentése a közfoglalkoztatottak hátteréröl és lehetöségeiröl (Public work trap. Report of the Hungarian Anti-Poverty Network on the background of public workers and their possibilities). Budapest: MSZH.

OECD (Organisation for Economic Co-operation and Development) (2014) Short-term labour market statistics. http://stats.oecd.org/ Index.aspx?DataSetCode=STLABOUR. [Accessed: 03-01-2016].

Putnam, R. D. (2000) Bowling alone: The Collapse and Revival of the American Community. New York, Simon and Schuster.

Rose, R. (1999) Getting Things Done in an Antimodern Society: Social Capital Networks in Russia. In Dasgupta, P. - Serageldin, I. (eds.) Social capital: A multifaceted perspective. World Bank: Washington D.C., 147-171.

SEI-T (Estonian Institute for Sustainable Development) (2004) Household Consumption Trends in New Member States. Background Study for European Environement Agency. Tallinn: SEI-I.

Schwarcz, Gy. (2012) Ethnicizing poverty through social security provision in rural Hungary. Journal of Rural Studies, 27 (1) 99-107. http://dx.doi.org/10.1016/j.jrurstud.2012.01.022.

Simonovits, B. - Szívós, P. (2012) A háztartások fogyasztása 2012-ben. In Szivós, P. - Tóth, I. Gy. (ed.) Egyenlőtlenség és polarizálódás a magyar társadalomban. TÁRKI, Monitor jelentések, 61-73.

Somai, M. (2013) World's Agricultural Production and Trade: Fodd Security at State? International Journal of Biotechnology for Wellness Industries, 2, 182-195. http://dx.doi.org/10.6000/1927-3037.2013.02.04.5.

Standing, G. (2011) The Precariat: The New Dangerous Class. London: Bloomsbury. http://dx.doi.org/10.5040/9781849664554.

Svendsen, G. L. H. - Svendsen, G. T. (2004) The Creation and Destruction of Social Capital, Entrepreneurship, Co-operative Movements and Institutions. Cheltenham: Edwards Elgar.

Swain, N. (1985) Collective farms which work? Cambridge: Cambridge University Press.

Szalai, J. (2007) Nincs két ország? Társadalmi küzdelmek az állami túlelosztásért a rendszerváltás utáni Magyarországon. Budapest: Osiris.

Szelényi, I. - Manchin, R. - Juhász, P. - Magyar, B. - Bill, M. (1988) Socialist Entrepreneurs, Embourgeoisement in Rural Hungary. Madison: The University of Wisconsin Press.

Szikra, D. (2014) Democracy and welfare in hard times: The social policy of the Orbán Government in Hungary between 2010 and 2014. Journal of European Social Policy, 24 (5): 486-500. http://dx.doi.org/10.1177/0958928714545446.

Szuhay, P. (2005) (Utó)parasztosodó törekvések a szendröládi romák körében. [(Post)peasantification aspirations among the Roma in Szendrőlád]. In Schwarcz, Gy. - Szarvas, Zs. - Szilágyi, M. (eds.) Utóparaszti hagyományok és modernizációs törekvések a magyar vidéken. Budapest: MTA Néprajzkutató Intézet, 59-74.

TASZ (Társaság a Szabadságjogokért) (2013) A Társaság a Szabadságjogokért jogvédő szervezet véleménye a szociális szövetkezetekkel összefüggésben egyes törvények, továbbá a közfoglalkoztatáshoz kapcsolódó egyes törvények módositásáról szóló T/10241. számú törvényjavaslatról [The opion of the civil rights association Association for Freedomrights on the modification of some laws in connection with social co-operatives and public work]. Budapest: Accessed 19 October, 2015, file:///C:/Users/ial01/ Documents/My\%20Documents/roma/acta\%20publication/tasz-velemeny-t.10241.pdf [Accessed: 19-10-2015].

Thelen, T. - Dorondel, S. - Szöke, A. - Vetter, L. (2011) The sleep has been rubbed from their eyes: social citizenship and the reproduction of local hierarchies in rural Hungary and Romania. Citizenship Studies, 15 (3-4): 513-527. http://dx.doi.org/10.1080/13621025.2011.564834.

UNDP (United Nations Development Programme) (2002) The Roma in Central and Eastern Europe: Avoiding the Dependency Trap. A Regional Human Development Report. Bratislava: Regional Bureau for Europe and the Commonwealth of Independent States. 
Yunus, M. and Weber, K. (2010) Building social business : the new kind of capitalism that serves humanity's most pressing needs, New York : Public Affairs,

Vajda, R. - Dupcsik, Cs. (2008) Country Report on Ethnic Relations: Hungary. Edumigrom, Budapest: CEU. Available at: http://www. romaeducationfund.hu/sites/default/files/documents/edumigrom_background_paper_hungary_ethnic.pdf. [Accessed: 03-012016]. 